\title{
In vitro degradation behaviour of biodegradable soy plastics: effects of crosslinking with glyoxal and thermal treatment
}

\author{
Cláudia M. Vaz ${ }^{\mathrm{a}, *}$, Leontine A. de Graaf ${ }^{\mathrm{b}}$, Rui L. Reis ${ }^{\mathrm{a}, \mathrm{c}}$, António M. Cunha ${ }^{\mathrm{a}}$ \\ a Department of Polymer Engineering, University of Minho, Campus de Azurém, 4800-058 Guimarães, Portugal \\ ${ }^{\mathrm{b}}$ ATO B.V., Agrotechnological Research Institute, PO Box 17, 6700 AA Wageningen, The Netherlands \\ ‘3B's Research Group - Biomaterials, Biodegradables and Biomimetics, University of Minho, Campus de Gualtar, 4710-057 Braga, Portugal
}

Received 4 November 2002; received in revised form 20 January 2003; accepted 1 February 2003

\begin{abstract}
In-vitro degradation of soy-derived protein materials, non-crosslinked $\left(\mathrm{SI}_{\mathrm{tp}}\right)$, crosslinked with glyoxal $\left(\mathrm{X}-\mathrm{SI}_{\mathrm{tp}}\right)$ or submitted to heat treatment $\left(24 \mathrm{TT}-\mathrm{SI}_{\mathrm{tp}}\right)$, was studied with either an isotonic saline solution without enzymatic activity or containing bacterial collagenase. The changes in weight of the samples during the in-vitro degradation were studied and compared with the variations of the mechanical properties. The weight loss of $\mathrm{SI}_{\mathrm{tp}}, \mathrm{X}-\mathrm{SI}_{\mathrm{tp}}$ and $24 \mathrm{TT}-\mathrm{SI}_{\mathrm{tp}}$ were more pronounced when using collagenase. After $24 \mathrm{~h}$ of immersion, $\mathrm{SI}_{\mathrm{tp}}$ lost $10.6 \%$ of its initial weight whereas $0.6 \mathrm{X}-\mathrm{SI}_{\mathrm{tp}}$ and $24 \mathrm{TT}-\mathrm{SI}_{\mathrm{tp}}$ lost 1.7 and $5.7 \%$, respectively. In every case, the weight loss was found to be directly proportional to the respective crosslinking degree: $2.4 \%$ for $\mathrm{SI}_{\mathrm{tp}}, 44 \%$ for $0.6 \mathrm{X}-\mathrm{SI}_{\mathrm{tp}}$ and $27.8 \%$ for $24 \mathrm{TT}-\mathrm{SI}_{\mathrm{tp}}$. Consequently, the susceptibility of the soy materials towards enzymatic degradation could be controlled by varying the degree of crosslinking of the samples. The mechanical properties proved to be more sensitive to the loss of plasticiser (glycerol) during immersion than to the degradation of the polymeric matrices. After $24 \mathrm{~h}$ of immersion all the materials presented an increase in stiffness and brittleness due to the complete leaching of glycerol from the matrices. $\mathrm{SI}_{\mathrm{tp}}, \mathrm{X}-\mathrm{SI}_{\mathrm{tp}}$ and $24 \mathrm{TT}-\mathrm{SI}_{\mathrm{tp}}$ proved to be suitable materials for either load-bearing applications or temporary applications such as tissue engineering scaffolds or drug delivery systems.
\end{abstract}

C) 2003 Elsevier Science Ltd. All rights reserved.

Keywords: Soy; Soy-derived protein material; Crosslinking; Mechanical properties; In-vitro degradation

\section{Introduction}

Several degradable polymers have been successfully used in biomedical applications. However, continuing research in the search for alternatives is suggested by some weaknesses of these materials, namely: i) the low level of degradability of some of these polymers, due to restrictions in their chemical nature [1-3]; and ii) eventual problems associated with the respective degradation products [4]. Furthermore, the demands for biomaterials with controlled and predictable degradation kinetics are numerous and have led to research on a variety of synthetic and natural polymers engineered for use in a wide range of medical applications.

* Corresponding author. Tel.: + 351-253-510-245; fax: +351-253510-249.

E-mail address: claudiavaz@dep.uminho.pt (C.M. Vaz).
During the last decades, aliphatic polyesters have been one of the most widely used classes of degradable polymers in the medical field [5-7]. Despite their wide applicability, many researchers are exploring new directions to address some of their current limitations, namely those related to their degradation mechanisms [4]. A variety of natural polymers, such as hyaluronic acids, alginates, starch and animal-origin proteins (namely, collagen, gelatine and albumin), are being extensively explored as potential biomaterials, particularly to be used in tissue regeneration scaffolds [8-10] and controlled release systems [11-15]. Among these naturally derived polymers, non-animal origin proteins, such as soy, may constitute a viable source of degradable materials for biomedical uses. In fact, they are expected to combine the main characteristics of collagen, gelatine and albumin with: i) a reduced susceptibility to thermal degradation (allowing for its easy processing by melt based technologies into complex $3 \mathrm{D}$ 
implants); and ii) an adequate degradation for the envisaged applications. Like the above described proteins, soy also proved to be non-cytotoxic, slightly immunogenic and bioactive when reinforced with bone like ceramics [16-18]. It has also been reported [19-22] that soy presents good processability, both in aqueous media and in the melt, and a reduced susceptibility to thermal degradation [23]. Soy is also expected to present an adequate degradation profile. In this case, it may be regarded as an eventual ideal template suitable for being used in biomedical applications. Temporary replacement implants, tissue engineering scaffolding or drug delivery systems are the most promising target applications.

However, due to the high enzymatic turnover rate of proteins in the human body, the stabilisation of proteinbased materials, by crosslinking methods, is required to assure the respective integrity and the desired mechanical properties during an implantation period [24,25]. Crosslinks in proteins can be created by a number of ways, namely by physical or chemical routes [26]. The most used agents for chemical crosslinking are aldehydes, namely formaldehyde and glutaraldehyde. However, concerns related with the use of these two agents arose from an exacerbating effect on the calcification of prosthesis materials [27], cytotoxicity due to postimplantation depolymerization and monomer release from the crosslinked materials [28,29]. A promising solution for biomedical purposes is glyoxal, a dialdehyde with lower toxicity [30], when compared with similar agents. Other alternative which requires no crosslinking agents is based on the use of a physical method: thermal treatments.

This paper reports on the in vitro degradation behaviour of soy plastics using an isotonic saline solution with or without bacterial collagenase (degrading enzyme present in the human body and active during an implantation process). Soy plastics were previously crosslinked using glyoxal and a thermal treatment. The susceptibility of the resulting materials towards degradation is analysed in terms of the following aspects of the tested samples: i) weight; ii) crosslinking density; and iii) mechanical properties.

\section{Materials and methods}

\subsection{Materials}

Loders Crocklaan BV (Wormerveer, The Netherlands) supplied the non-GMO soy protein isolate (SI, $83.4 \%$ protein, $\mathrm{w} / \mathrm{w}$ on dry weight base). Glycerol, glyoxal $(40 \% \mathrm{v} / \mathrm{v})$ and $o$-phthaldialdehyde (OPA) were used as received from the manufacturer, Sigma-Aldrich Chemie BV (Zwijndrecht, The Netherlands). $\mathrm{NaCl}$, $\mathrm{NaOH}$ and $\mathrm{HCl}$ were all of analytical grades.

\subsection{Production of soy specimens}

Native soy protein was converted into a thermoplastic material $\left(\mathrm{SI}_{\mathrm{tp}}\right)$ in a co-rotating twin-screw extruder as described previously in [22]. During the extrusion procedure, the soy protein was also crosslinked with different amounts of glyoxal, namely $0,0.3$ and $0.6 \% \mathrm{w} / \mathrm{w}$ based on the protein content $\left(\mathrm{SI}_{\mathrm{tp}}, 0.3 \mathrm{X}-\mathrm{SI}_{\mathrm{tp}}\right.$ and $0.6 \mathrm{X}$ $\mathrm{SI}_{\mathrm{tp}}$, respectively). The extruded thermoplastic materials (in the form of pellets) were moulded into ASTM tensile test bars $\left(2 \times 4 \mathrm{~mm}^{2}\right.$ of cross section), as described in [22]. A batch of the injection-moulded specimens $\left(\mathrm{SI}_{\mathrm{tp}}\right)$ was submitted to a thermal treatment performed at $80{ }^{\circ} \mathrm{C}$ during $24 \mathrm{~h}\left(24 \mathrm{TT}-\mathrm{SI}_{\mathrm{tp}}\right)$.

\subsection{Degradation tests}

\subsubsection{Non-enzymatic degradation}

Non-crosslinked and crosslinked samples were submitted to in vitro degradation tests. Pre-weighed dry specimens were immersed for $0,1,3,5,7$ and 14 days, at $37{ }^{\circ} \mathrm{C}$, in an isotonic saline solution [ISS- $\mathrm{NaCl}, 9 \mathrm{~g} /$ $1+1 \%$ sodium azide $\left.\left(\mathrm{NaN}_{3}\right)\right]$ buffered at $\mathrm{pH}=7.40 \pm 0.02$ with a $0.2 \mathrm{M}$ tris(hydroxymethyl) aminomethane $/ 0.2 \mathrm{M}$ hydrochloric acid $(\mathrm{HCl})$ buffer $(0.2 \mathrm{M}$ Tris- $\mathrm{HCl}$ buffer).

\subsubsection{Enzymatic degradation with collagenase}

The degradation of the non-crosslinked and the crosslinked soy samples was also evaluated using bacterial collagenase from Clostridium histolyticum (EC 3.4.24.3, Sigma-Aldrich Chemie BV, Zwijndrecht, The Netherlands) with an activity of $283 \mathrm{U} / \mathrm{mg}$ (one unit releases peptides from native collagen equivalent in ninhydrin color to $1 \mu \mathrm{mol}$ of L-leucine in $5 \mathrm{~h}$ at $\mathrm{pH} 7.4$ at $37{ }^{\circ} \mathrm{C}$ in the presence of calcium ions). In a typical experiment, samples of the different soy materials were immersed for $0,3,6,24$ and $72 \mathrm{~h}$, at $37{ }^{\circ} \mathrm{C}$, in an isotonic saline solution (as described in Section 2.3.1) with collagenase $(100 \mathrm{U} / \mathrm{ml})$. The degradation was stopped at the desired time interval by addition of $0.2 \mathrm{ml}$ of $0.25 \mathrm{M}$ EDTA (Merck, Darmstadt, Germany) solution. The mixtures were cooled in ice. The remained soy specimens were washed with the Tris- $\mathrm{HCl}$ buffer and deionized water before determination of the respective weight loss.

\subsection{Degradation products}

\subsubsection{Protein content}

After ageing, samples were ground using liquid $\mathrm{N}_{2}$ and subsequently sieved with a mesh size of $1 \mathrm{~mm}$. 50 $\mathrm{mg}$ of protein samples was dispersed in a mixture of deionized water and concentrated $\mathrm{H}_{2} \mathrm{SO}_{4}$. After adequate digestion of the protein samples, carried out at $420{ }^{\circ} \mathrm{C}$ during $50 \mathrm{~min}$, the total protein content $\left(N_{\text {tot }}\right)$ of 
the resulting solution was determined by Kjeldahl analysis and calculated as:

$N_{\mathrm{tot}}(\%)=\left[[V(\mathrm{HCl}) * 0.1 * 14 * 6.25] / W_{\mathrm{d}}\right] * 100$

where, $V(\mathrm{HCl})$ is the volume of $\mathrm{HCl} 0.1 \mathrm{M}$ used during the Kjeldahl titration, 14 is the atomic mass of nitrogen $(N)$ and 6.25 the Kjeldahl factor of soy. $W_{\mathrm{d}}$ is the dry weight of the protein powder sample tested.

\subsubsection{Free amino groups measurement}

The free amino group content was determined using the OPA method [31] for all the samples aged for 0 and $24 \mathrm{~h}$. An OPA solution was made by mixing $25 \mathrm{ml}$ of 0.1 M sodium borate ( $\mathrm{pH} 9.2$ ), $2.5 \mathrm{ml}$ of $20 \%(\mathrm{w} / \mathrm{w})$ SDS and $40 \mathrm{mg}$ of OPA (dissolved in $1 \mathrm{ml}$ methanol) and 100 $\mu 1$ of $\beta$-mercaptoethanol. The final volume was adjusted to $50 \mathrm{ml}$ with deionized water. To determine the degree of alkylation, an aliquot ( $50 \mu 1$ containing $2 \mathrm{~g} / 1$ protein in sodium tetraborate buffer $0.0125 \mathrm{M}+2 \%$ SDS) was added directly to $1.0 \mathrm{ml}$ of OPA reagent in a cuvette. The solution was mixed rapidly and incubated for $2 \mathrm{~min}$ at room temperature before the absorbency was read at $340 \mathrm{~nm}$ against water. A calibration curve was previously established by using L-leucine as a standard.

\subsubsection{Carboxylic groups measurement}

An adapted titration was used for measuring the amount of terminal carboxylic groups in the soy materials [32].

$0.33 \mathrm{~g}$ of noncrosslinked and crosslinked soy materials was dispersed in $50 \mathrm{ml}$ of deionized water. An automatic titrator (Titronic 97/20) was used to adjust, under magnetic stirring, the $\mathrm{pH}$ of the solutions to 7 using 0.1 $\mathrm{M} \mathrm{HCl}$ or $0.1 \mathrm{M} \mathrm{NaOH}$ in order to have the zwitterionic form of the protein in solution: ${ }^{+} 3 \mathrm{HN}-\mathrm{RH}-$ $\mathrm{COO}^{-}$. It is assumed that the amounts of $\mathrm{HCl}$ needed to go from $\mathrm{pH} 6$ to $\mathrm{pH} 3\left({ }^{+} 3 \mathrm{HN}-\mathrm{RH}-\mathrm{COOH}\right)$ correspond to the amount of carboxyl groups.

\subsubsection{Buffer diffusion coefficients}

To determine the buffer diffusion coefficients of the specimens, swelling tests were performed. The specimens were immersed up to $24 \mathrm{~h}$ in both degrading solutions described in Sections 2.3.1. and 2.3.2.

The wet weight of the specimens was determined by first blotting the specimen with filter paper to remove adsorbed buffer on the surface, and then weighed immediately on an electronic balance [33]. The following Eq. (2) was used to determine the buffer diffusion coefficient, $D$ [34]:

$W_{\mathrm{t}} / W_{\mathrm{e}}=4 *\left[D /\left(\pi * h^{2}\right)\right]^{0.5} * t^{0.5}$

where, $W_{\mathrm{t}}$ and $W_{\mathrm{e}}$ denote, respectively, the weight increase due to the buffer absorption at time $t$ and at equilibrium time. $D$ is the diffusion coefficient and, considering that absorption occurs from both sides of the sample, $h$ is the overall thickness of the sample.

\subsubsection{Weight loss}

After each ageing period, the samples were removed from the degradation solution, washed with distilled water and dried in a vacuum oven $\left(40{ }^{\circ} \mathrm{C} / 24 \mathrm{~h}\right)$ [33]. The percentage weight loss of the soy materials was then calculated from Eq. (3):

$\mathrm{WL}_{t}=\left[\left(W_{0} * N_{0}-W_{t} * N_{t}\right) /\left(W_{0} * N_{0}\right)\right] * 100$

where $\mathrm{WL}_{t}$ is the weight loss of after a certain time $t$ of immersion. $W_{t}$ denotes the weight of the specimen at ageing time $t$ and $N_{t}$ the respective protein content at that ageing time, $W_{0}$ is the initial dry weight of the specimen and $N_{0}$ the correspondent protein content. Each experiment was repeated three times and the average value was taken as the weight loss.

\subsubsection{Dimensional variation}

Before tensile testing, all the aged specimens were accurately measured for its thickness $(h)$. This allowed for the evaluation of the surface erosion of the specimens as a function of immersion time.

\subsubsection{Mechanical properties}

Crosslinked and non-crosslinked samples aged for 0 , $3,6,24$ and $72 \mathrm{~h}$ in the isotonic saline solutions with and without enzymatic activity where conditioned for 1 week in a chamber at $25^{\circ} \mathrm{C}$ and $90 \%$ relative humidity before testing for its mechanical properties. The measurements were assessed in tensile mode. The experiments were performed in a Zwick Z010 universal mechanical testing machine, in a controlled chamber $\left(20{ }^{\circ} \mathrm{C}\right.$ and $\left.55 \% \mathrm{RH}\right)$. A $5 \mathrm{kN}$ load cell, a pre-load of $0.1 \mathrm{~N}$ and a loading speed of $1 \mathrm{~mm} / \mathrm{min}$ were used. Emodulus at $0.05-0.25 \%$ strain $\left(E_{0.05-0.25 \%}\right)$, yield stress $\left(\sigma_{\mathrm{y}}\right)$ and strain at break $\left(\varepsilon_{\mathrm{b}}\right)$ were computed from the respective data.

\subsubsection{Moisture content}

After tensile testing, specimens were milled using liquid $\mathrm{N}_{2}$ and weighed into aluminium dishes for subsequent drying for $24 \mathrm{~h}$ in a vacuum oven at $40{ }^{\circ} \mathrm{C}$ [33]. Moisture content (MC) was determined in triplicate for each type of material as percentage of initial weight $\left(W_{0}\right)$ lost during drying $\left(W_{0 \mathrm{~d}}\right)$ :

$\mathrm{MC}=\left[\left(W_{0}-W_{0 \mathrm{~d}}\right) / W_{0}\right] * 100$

\subsubsection{Molecular weight distributions}

To a SDS-PAGE sample (containing at least $50 \mathrm{mg}$ of the specimen degraded for 0,3 and 14 days), $6 \mathrm{ml}$ of electrophoresis buffer $(50 \mathrm{mM}$ Tris- $\mathrm{HCl} \mathrm{pH} 6.8,12 \%$ 
glycerol $\mathrm{w} / \mathrm{v}, 4 \% \operatorname{SDS} \mathrm{w} / \mathrm{v}, 2 \% \beta$-mercaptoethanol $\mathrm{w} / \mathrm{v}$ and bromophenyl blue) was added and left standing at room temperature for $2 \mathrm{~h}$ with vortexing every $15 \mathrm{~min}$. Subsequently, the mixture was centrifuged at $8000 \times g$ for $10 \mathrm{~min}$. The supernatant was kept at $-20^{\circ} \mathrm{C}$ for later electrophoresis.

Before electrophoresis, the supernatant was boiled for 5 min to break the S-S bonds. Subsequently, it was cooled down and applied to a gel prepared from $15 \%$ acrylamide. High molecular standards (phosphorylase b: 94,000 D; BSA: 67,000 D; ovalbumin: 43,000 D; carbonic anhydrase: $30,000 \mathrm{D}$; soybean trypsin inhibitor: 20,100 D; $\alpha$-lactalbumin: 14,437 D) from Pharmacia (Uppsala, Sweden) were used as protein references. The electrophoresis was conducted using a II Dual Slab Cell system (Bio-Rad, Veenendal, The Netherlands) at a voltage of $150 \mathrm{~V}$ which was increased to $200 \mathrm{~V}$ when the protein reached the dividing line between the stacking and the separating gels. The gels were stained using Serva Blue $\mathrm{R}$ for $45 \mathrm{~min}$ and destained by immersion in a solution of methanol:acetic acid:dionized water (4:1:5) for at least $3 \mathrm{~h}$. After decolouration, the gels were dried in a coating dryer (Bio-Rad Laboratories) for $1 \mathrm{~h}$ at $60{ }^{\circ} \mathrm{C}$.

\section{Results}

\subsection{Weight loss}

\subsubsection{Glyoxal crosslinking}

The crosslinking of the soy samples with glyoxal was related to the correspondent in-vitro degradation behaviour. First, the number of free carboxyl and free amine groups of the developed compounds were determined to quantify the crosslinking density (Table 1).

The results confirmed that glyoxal crosslinking occurred via the free amine groups of the lysine (or hydroxylysine) residues, which decrement is observed for higher amounts of the crosslinking agent

The weight loss of the materials with different degrees of crosslinking, as a function of degradation time, is presented in Figs. 1 and 2.

Table 1

The content of amine and carboxyl groups of soy crosslinked with glyoxal and heat treated soy

\begin{tabular}{lll}
\hline Materials & $\begin{array}{l}\text { Free amine group } \\
\text { content }(\%)\end{array}$ & $\begin{array}{l}\text { Carboxyl group content } \\
(\mathrm{mmol} / 100 \text { g protein })\end{array}$ \\
\hline $\mathrm{SI}_{\mathrm{tp}}$ & $97.6 \pm 0.5$ & $108.3 \pm 0.002$ \\
$0.3 \mathrm{X}-\mathrm{SI}_{\mathrm{tp}}$ & $66.3 \pm 1.1$ & $110.5 \pm 0.009$ \\
$0^{-6 \mathrm{X}-\mathrm{SI}_{\mathrm{tp}}}$ & $55.9 \pm 1.0$ & $111.3 \pm 0.003$ \\
24T-SI $_{\mathrm{tp}}$ & $72.2 \pm 1.1$ & $112.1 \pm 0.007$ \\
\hline
\end{tabular}

$\mathrm{SI}_{\mathrm{tp}}$ : soy protein thermoplastic; $\# \mathrm{X}-\mathrm{SI}_{\mathrm{tp}}$ : soy protein thermoplastic crosslinked with \#\% glyoxal ( $\%$ based on the protein content); 24TT$\mathrm{SI}_{\mathrm{tp}}$ : heat treated soy protein thermoplastics.
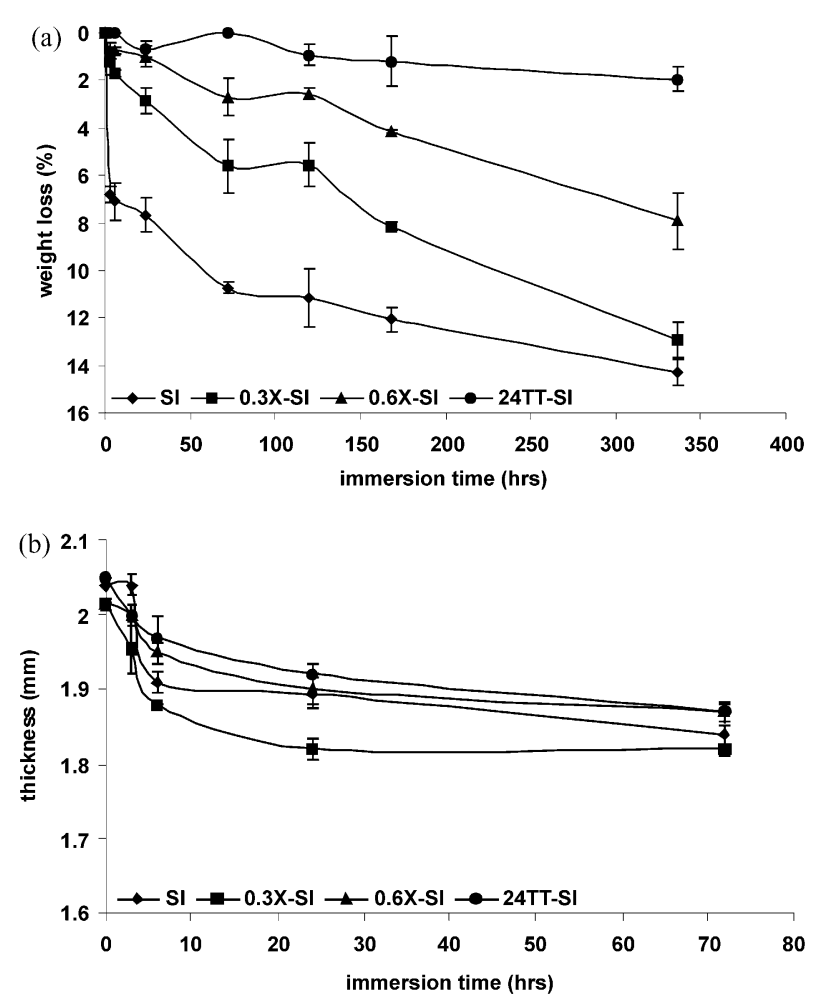

Fig. 1. Changes in (a) weight and (b) thickness of soy protein based materials as a function of degradation time during exposure to an isotonic saline solution $\left(\mathrm{NaCl} 9 \mathrm{~g} / 1, \mathrm{pH} 7.4\right.$ and $\left.37^{\circ} \mathrm{C}\right)$.
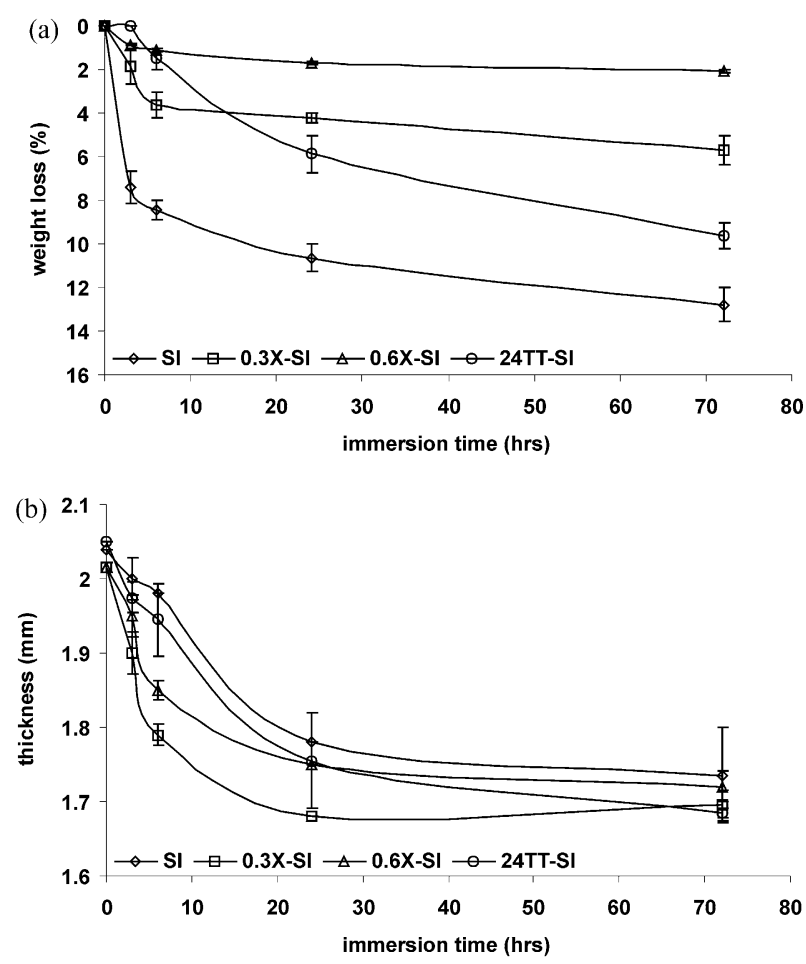

Fig. 2. Changes in (a) weight and (b) thickness of soy protein based materials as a function of degradation time during exposure to an isotonic saline solution with bacterial collagenase $(100 \mathrm{U} / \mathrm{ml}, \mathrm{pH} 7.4$ and $37^{\circ} \mathrm{C}$ ). 
Two different immersion media were used: i) without enzymes; and ii) with bacterial collagenase, respectively. The material having the highest degree of crosslinking showed the highest resistance against hydrolysis and the lowest coefficients of diffusion (Table 2).

An almost linear decrease in the material weight loss was observed for different degrees of crosslinking (Fig. 3).

Although the diffusion coefficients of the enzymatic solution were always lower than those of the non-enzymatic one (Table 2), all the materials showed a slightly higher susceptibility towards degradation by collagenase. The weight loss rates, determined from the slopes of the initial linear part of the curves displayed in

Table 2

Diffusion coefficients of the tested degradation solutions into the (non)-crosslinked and heat treated soy samples

\begin{tabular}{lll}
\hline Materials & \multicolumn{2}{l}{$D \times 10^{-8}\left(\mathrm{~cm}^{2} / \mathrm{s}\right)$} \\
\cline { 2 - 3 } & ISS & ISS + collagenase \\
\hline SI $_{\mathrm{tp}}$ & 62.5 & 59.1 \\
$0.6 \mathrm{X}-\mathrm{SI}_{\mathrm{tp}}$ & 46.0 & 42.1 \\
$24 \mathrm{TT}-\mathrm{SI}_{\mathrm{tp}}$ & 52.6 & 48.4 \\
\hline
\end{tabular}

$\mathrm{SI}_{\mathrm{tp}}$ : soy protein thermoplastic; $\# \mathrm{X}-\mathrm{SI}_{\mathrm{tp}}$ : soy protein thermoplastic crosslinked with \#\% glyoxal ( $\%$ based on the protein content); 24TT$\mathrm{SI}_{\mathrm{tp}}$ : heat treated soy protein thermoplastics; $D$ : diffusion coefficient; ISS: isotonic saline solution, $\mathrm{NaCl} 9 \mathrm{~g} / 1$, buffered at $\mathrm{pH} 7.4$ with $0.2 \mathrm{M}$ Tris- $\mathrm{HCl}$.
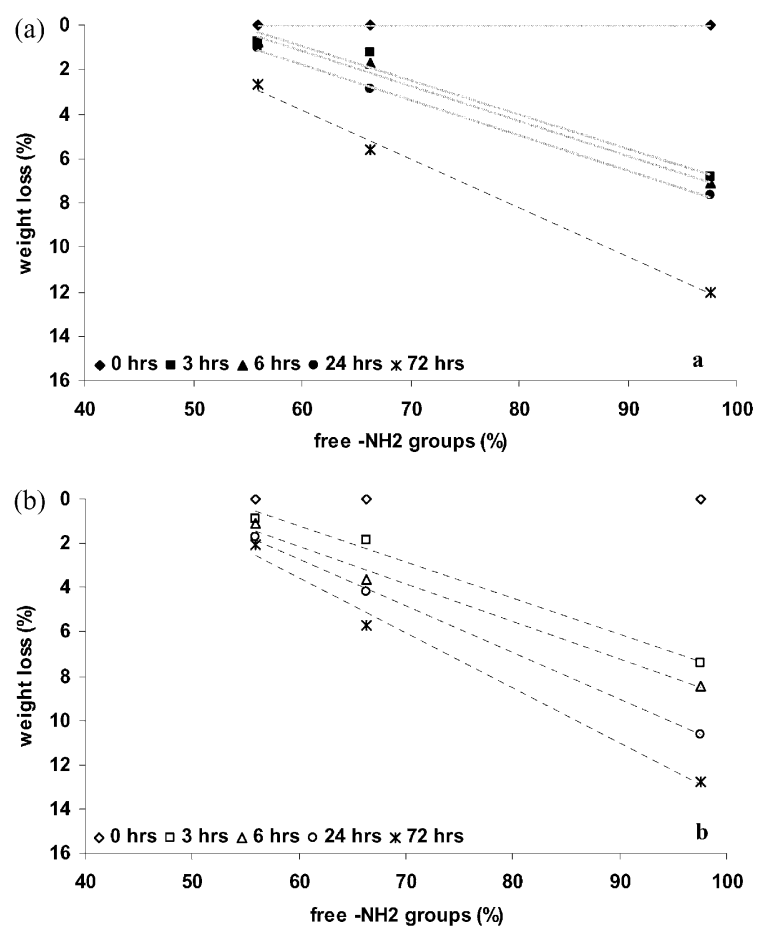

Fig. 3. Change in weight of soy protein based materials as a function of the respective crosslinking degree in (a) isotonic saline solution $(9 \mathrm{~g} /$ $1 \mathrm{NaCl}, \mathrm{pH} 7.4,37^{\circ} \mathrm{C}$ ) or (b) isotonic saline solution with bacterial collagenase $\left(100 \mathrm{U} / \mathrm{ml}, \mathrm{pH} 7.4,37^{\circ} \mathrm{C}\right)$.
Fig. 1, are presented in Fig. 4 as a function of the amount of free amine groups in the protein.

A decrease in free amine groups results in a lower degradation rate. It appears that a crosslinking degree of $50 \%$ must be reached, above which only slow degradation is observed in both media.

\subsubsection{Heat treatment}

The free amine group and the carboxyl contents of the heat treated soy materials are given in Table 1. Fig. 5

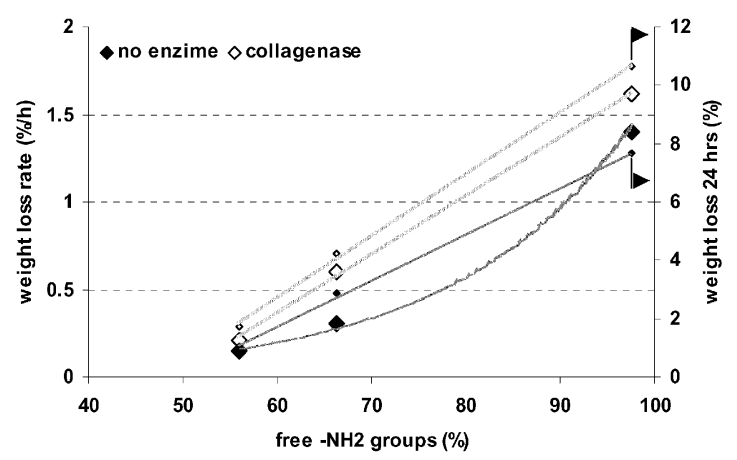

Fig. 4. Rate of weight loss $(\diamond, \diamond)$ and weight loss for $24 \mathrm{~h}(\diamond, \diamond)$ of soy crosslinked with $0,0.3$ and $0.6 \%$ glyoxal $\left(\mathrm{SI}_{\mathrm{tp}}, 0.3 \mathrm{X}-\mathrm{SI}_{\mathrm{tp}}\right.$ and $0.6 \mathrm{X}-$ $\mathrm{SI}_{\mathrm{tp}}$, respectively) during immersion in an isotonic saline solution ( $\bullet$, ., $9 \mathrm{~g} / \mathrm{l} \mathrm{NaCl}, \mathrm{pH} 7.4,37{ }^{\circ} \mathrm{C}$ ) or in an isotonic saline solution with bacterial collagenase $\left(\diamond, \diamond, 100 \mathrm{U} / \mathrm{ml}, \mathrm{pH} 7.4,37^{\circ} \mathrm{C}\right)$ as a function of the degree of crosslinking of the tested materials.
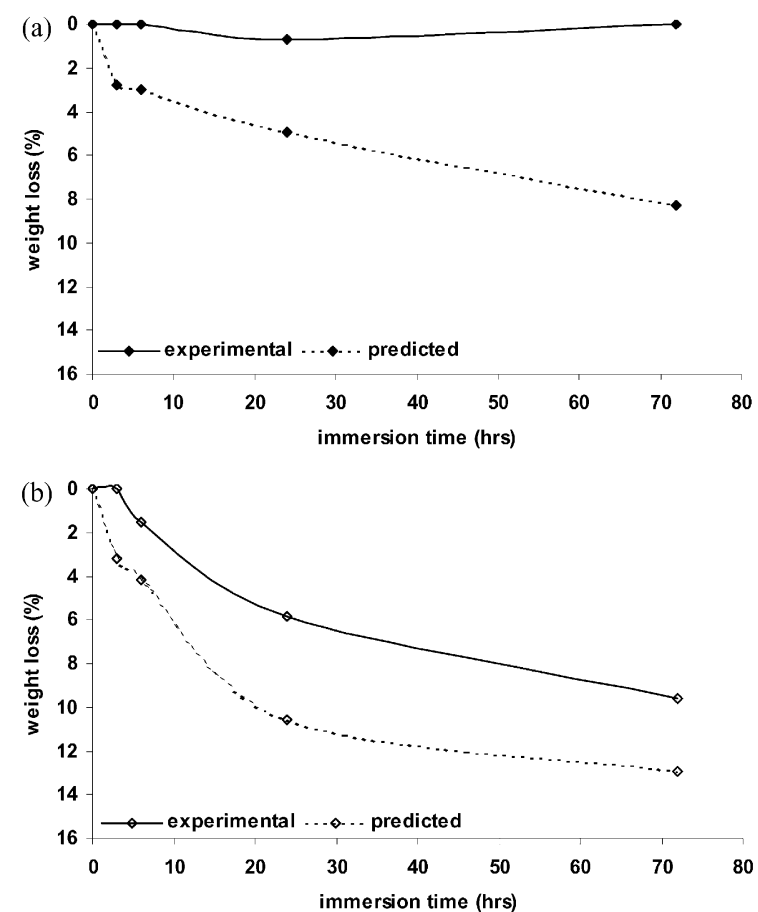

Fig. 5. Experimental and theoretically expected change in weight of the heat treated soy $\left(24 \mathrm{TT}-\mathrm{SI}_{\mathrm{tp}}\right)$ tested in (a) isotonic saline solution ( 9 $\mathrm{g} / 1 \mathrm{NaCl}, \mathrm{pH} 7.4,37^{\circ} \mathrm{C}$ ) or (b) isotonic saline solution with bacterial collagenase $\left(100 \mathrm{U} / \mathrm{ml}, \mathrm{pH} 7.4,37{ }^{\circ} \mathrm{C}\right)$, considering the respective crosslinking degree. 
presents the weight loss of the heat treated soy plotted as a function of the immersion time. The represented lines were determined in two different ways: i) experimental: using the procedure described in Section 2.3.3; and ii) predicted: only considering the effect of the amount of free amine groups (using the linear curve fitting of the results presented in Fig. 3).

The heat treated materials present a smaller susceptibility towards non-enzymatic degradation than the glyoxal crosslinked ones (Fig. 1a). By the contrary, when submitted to enzymatic media showed faster release rates (Fig. 2a). From the results presented in Fig. 5 it is possible to conclude that the crosslinking through the amine groups of soy should not be the only mechanism responsible for the degradation behaviour of the heat treated soy materials. The experimental degradation rates observed for heat treated soy are always slower than the theoretical predictions based only on the amine groups reactions (Fig. 5).

\subsection{Mechanical properties}

The change in mechanical properties of non-crosslinked soy $\left(\mathrm{SI}_{\mathrm{tp}}\right)$, soy crosslinked with glyoxal $(0.6 \mathrm{X}$ $\left.\mathrm{SI}_{\mathrm{tp}}\right)$ and heat treated soy $\left(24 \mathrm{TT}-\mathrm{SI}_{\mathrm{tp}}\right)$ as function of degradation time was evaluated. The content of amine groups and the mechanical properties of the soy materials are presented in Table 3 .

The mechanical properties of the soy materials depend on the crosslinking methodology. Crosslinking with glyoxal $\left(0.6 \mathrm{X}-\mathrm{SI}_{\mathrm{tp}}\right)$ resulted in materials which have a decreased tensile strength and strain at break and an increased stiffness as compared to $\mathrm{SI}_{\mathrm{tp}}$. Heat treatment afforded a material with a higher tensile strength and stiffness and lower strain at break as compared to $\mathrm{SI}_{\mathrm{tp}}$.

\subsubsection{Non-enzymatic degradation}

After $24 \mathrm{~h}$ of immersion, non-crosslinked soy $\left(\mathrm{SI}_{\mathrm{tp}}\right)$ retained over $92 \%$ of its original weight, whereas a $1 \%$ and $0.7 \%$ decrease in weight were observed for glyoxal crosslinked soy $\left(0.6 \mathrm{X}-\mathrm{SI}_{\mathrm{tp}}\right)$ and heat treated soy (24TT$\mathrm{SI}_{\mathrm{tp}}$ ), respectively. During degradation, the free amine group content of $\mathrm{SI}_{\mathrm{tp}}$ increased from 97.6 to $100 \%$, from 55.9 to $60.5 \%$ for $0.6 \mathrm{X}-\mathrm{SI}_{\mathrm{tp}}$ and from 72.2 to $80.2 \%$ for $24 \mathrm{TT}-\mathrm{SI}_{\mathrm{tp}}$.

The mechanical properties of $\mathrm{SI}_{\mathrm{tp}}, 0.6 \mathrm{X}-\mathrm{SI}_{\mathrm{tp}}$ and $24 \mathrm{TT}-\mathrm{SI}_{\mathrm{tp}}$ were reasonably affected upon degradation, as shown in Fig. 6.

An increase of the E-modulus was observed for all materials. The tensile strength also increased from 3.5 to 8.7 $\mathrm{MPa}$ for $\mathrm{SI}_{\mathrm{tp}}$ and from 3.9 to $9.4 \mathrm{MPa}$ for 24TT$\mathrm{SI}_{\mathrm{tp}}$. By the contrary, glyoxal crosslinked soy showed a slight decrease in this property (from 3.1 to $2 \mathrm{MPa}$ ). Furthermore, the strain at break was highly decreased from: i) $36.4-5.5 \%$ for $\mathrm{SI}_{\mathrm{tp}}$; ii) $25.5-1.8 \%$ for $0.6 \mathrm{X}-\mathrm{SI}_{\mathrm{tp}}$; and iii) $21.7-9.8 \%$ for $24 \mathrm{TT}-\mathrm{SI}_{\mathrm{tp}}$.

\subsubsection{Collagenase degradation}

The effect of collagenase on the mechanical properties of $\mathrm{SI}_{\mathrm{tp}}, 0.6 \mathrm{X}-\mathrm{SI}_{\mathrm{tp}}$ and $24 \mathrm{TT}-\mathrm{SI}_{\mathrm{tp}}$, as a function of immersion time, is presented in Fig. 7.

After $24 \mathrm{~h}$ of immersion, non-crosslinked soy $\left(\mathrm{SI}_{\mathrm{tp}}\right)$ retained over $89 \%$ of its original weight, whereas a $1.7 \%$ decrease in weight was obtained for glyoxal crosslinked soy $\left(0.6 \mathrm{X}-\mathrm{SI}_{\mathrm{tp}}\right)$. The $24 \mathrm{TT}-\mathrm{SI}_{\mathrm{tp}}$ material seemed to be the most affected by the collagenase action. After $24 \mathrm{~h}$ of immersion, it suffered a decrease of $6 \%$ in weight compared to the only $0.7 \%$ decrease observed during the non-enzymatic tests. During degradation, the free amine group content of $\mathrm{SI}_{\mathrm{tp}}$ increased from 97.6 to $100 \%$, from 55.9 to $68.1 \%$ for $0.6 \mathrm{X}-\mathrm{SI}_{\mathrm{tp}}$ and from 72.2 to $97.7 \%$ for $24 \mathrm{TT}-\mathrm{SI}_{\mathrm{tp}}$.

The mechanical properties of $\mathrm{SI}_{\mathrm{tp}}$ and $0.6 \mathrm{X}-\mathrm{SI}_{\mathrm{tp}}$ were not further affected by the presence of collagenase. By the contrary, heat treated soy was the most affected by the enzymatic action. It was observed a lower increase in stiffness and strength when compared with those observed during immersion in the non-enzymatic medium. The strain at break also decreased. It was observed a decrease from 21.7 to $9.8 \%$ for the non-enzymatic medium compared with a decrease from 21.7 to $5.3 \%$ for the medium with collagenase.

\subsection{Molecular weight distributions}

SDS-PAGE patterns of the soy thermoplastics $\left(\mathrm{SI}_{\mathrm{tp}}\right.$, $0.6 \mathrm{X}-\mathrm{SI}_{\mathrm{tp}}$ and $24 \mathrm{TT}-\mathrm{SI} \mathrm{t}_{\mathrm{tp}}$ ) were obtained to examine the

Table 3

Amine group content and mechanical properties of (non)-crosslinked and heat treated soy

\begin{tabular}{llllll}
\hline Material & $\begin{array}{l}\text { Free- } \mathrm{NH}_{2} \text { group } \\
\text { content (\%) }\end{array}$ & $\begin{array}{l}\text { Tensile strength } \\
(\mathrm{MPa})\end{array}$ & $\begin{array}{l}\text { Strain at } \\
\text { break (\%) }\end{array}$ & $\begin{array}{l}E_{0.05-0.25 \%^{-}} \\
\text {modulus (MPa) }\end{array}$ \\
\hline $\mathrm{SI}_{\text {tp }}$ & $97.6 \pm 0.5$ & $3.5 \pm 0.3$ & $36.4 \pm 0.5$ & $33 \pm 10$ & $\begin{array}{l}\text { Moisture } \\
\text { content (\%) }\end{array}$ \\
0.6X-SI & $55.9 \pm 1.0$ & $3.1 \pm 0.1$ & $25.5 \pm 4.7$ & $68 \pm 1$ & $16.8 \pm 0.2$ \\
$24 \mathrm{TT}-\mathrm{SI}_{\text {tp }}$ & $72.2 \pm 1.1$ & $3.9 \pm 0.1$ & $21.7 \pm 2.1$ & $88 \pm 3$ & $16.3 \pm 0.1$ \\
\hline
\end{tabular}

$\mathrm{SI}_{\mathrm{tp}}$ : soy protein thermoplastic; $0.6 \mathrm{X}-\mathrm{SI}_{\mathrm{tp}}$ : soy protein thermoplastic crosslinked with $0.6 \%$ glyoxal ( $\%$ based on the protein content); $24 \mathrm{TT}-\mathrm{SI}_{\mathrm{tp}}$ : heat treated soy protein thermoplastics. 

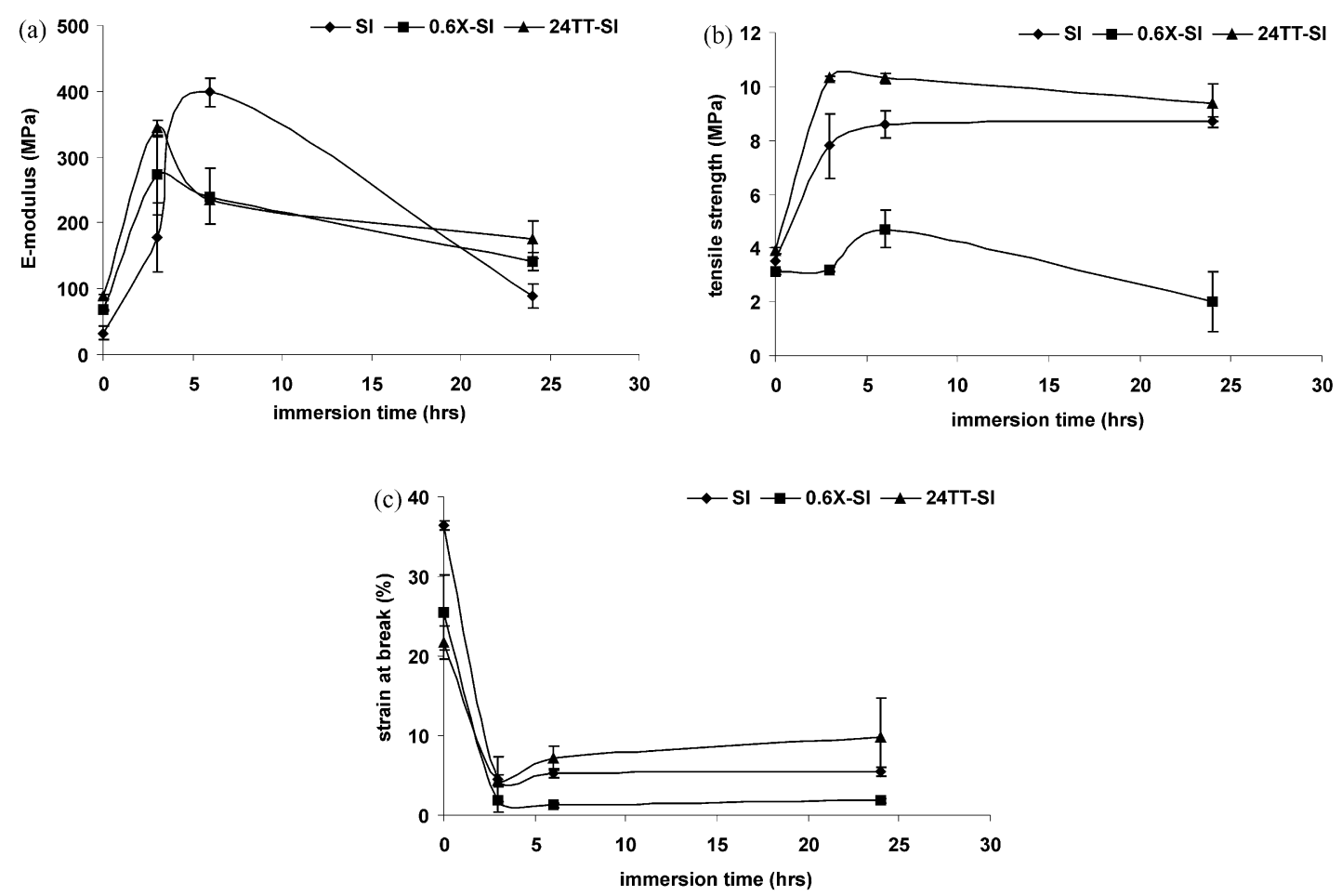

Fig. 6. Changes in (a) E-modulus, (b) tensile strength and (c) strain at break as a function of degradation time during exposure to an isotonic saline solution $\left(\mathrm{NaCl} 9 \mathrm{~g} / \mathrm{l}, \mathrm{pH} 7.4\right.$ and $\left.37^{\circ} \mathrm{C}\right)$.
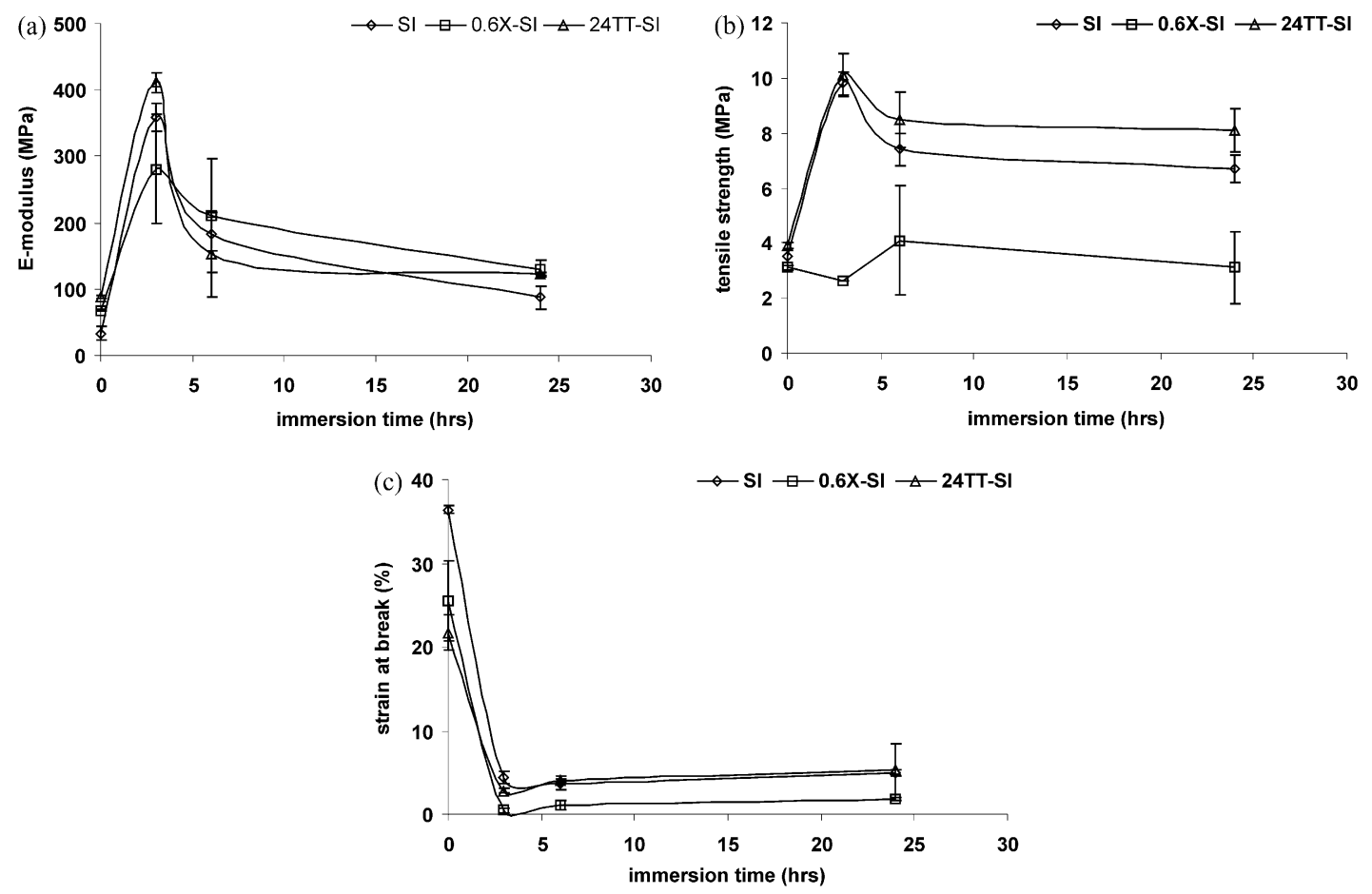

Fig. 7. Changes in (a) E-modulus, (b) tensile strength and (c) strain at break as a function of degradation time during exposure to an isotonic saline solution with bacterial collagenase $\left(100 \mathrm{U} / \mathrm{ml}, \mathrm{pH} 7.4\right.$ and $\left.37^{\circ} \mathrm{C}\right)$. 


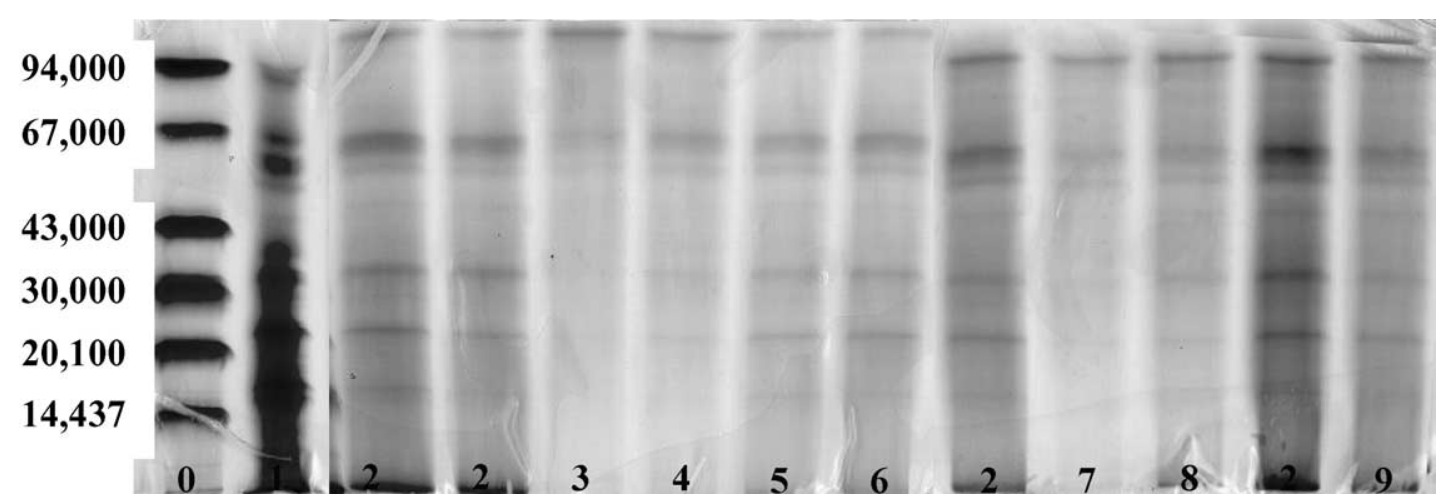

Fig. 8. SDS-PAGE results for standard: (0) protein markers; (1) native soy isolate; (2) thermoplastic soy ( $\left.\mathrm{SI}_{\mathrm{tp}}\right)$; (3) heat treated soy (24TT-SI $\left.{ }_{\mathrm{tp}}\right)$; (4) glyoxal crosslinked soy (0.6X-SI $\mathrm{St}_{\mathrm{tp}}$ ); (5) $\mathrm{SI}_{\mathrm{tp}}$ after 3 days immersion; (6) 24TT-SI $\mathrm{tp}_{\mathrm{tp}}$ after 3 days immersion; (7) $0.6 \mathrm{X}-\mathrm{SI}_{\mathrm{tp}}$ after 3 days immersion; (8) $\mathrm{SI}_{\mathrm{tp}}$ after 14 days immersion; (9) $24 \mathrm{TT}-\mathrm{SI}_{\mathrm{tp}}$ after 14 days immersion in an isotonic saline solution $\left(\mathrm{NaCl} 9 \mathrm{~g} / 1, \mathrm{pH} 7.4\right.$ and $\left.37^{\circ} \mathrm{C}\right)$.

molecular weight distributions of the proteins after different degradation periods (Fig. 8).

All the thermoplastics soy materials presented a large band on the top of the gel $\left(M_{w}>94,000 \mathrm{D}\right)$ which was absent in the soy isolate. Thus, the average molecular weight was slightly increased by extrusion and injection moulding operations, indicating that some intermolecular bonds were formed during processing. Glyoxal crosslinked samples $\left(0.6 \mathrm{X}-\mathrm{SI}_{\mathrm{tp}}\right)$ showed a very weak intensity, partly reflecting the low solubility of this protein in the electrophoresis. Heat treated samples $\left(24 \mathrm{TT}-\mathrm{SI}_{\mathrm{tp}}\right)$ also showed a band intensity weaker than SI but stronger than $0.6 \mathrm{X}-\mathrm{SI}_{\mathrm{tp}}$, proving its lower degree of crosslinking. After degradation, all the protein patterns showed a decrease of intensity of the fractions correspondent to a lower $\mathrm{Mw}$, and reflecting the preferential leaching of these fractions during the degradation tests. This observation was specially visible for $\mathrm{SI}_{\mathrm{tp}}$ confirming its higher susceptibility to degradation than the correspondent crosslinked matrices.

\section{Discussion}

The degradation behaviour of protein-based materials can be controlled by the respective degree of crosslinking (induced by chemical or physical methods). Traditionally, glutaraldehyde, carbodiimides and epoxy compounds have been extensively used as crosslinking agents to stabilise arteries and pericardial heart valves [35-37].

The resistance against degradation of protein based materials can be studied by in-vitro tests, in isotonic saline solutions, including (or not) enzymes such as bacterial collagenase, and is mainly monitored by changes in weight as a function of the immersion time. The selected collagenase enzyme from Clostridium histolyticum is capable of cleaving peptide bonds within the protein structure and has a specificity for the Pro-XGly-Pro-Y region, splitting between X and Gly where X and $\mathrm{Y}$ are predominantly apolar amino acid residues. So, the degradation rate of the protein-based material will be mainly determined by the crosslinking density, the accessibility of the cleavage sites and the extent of denaturation $[24,25]$. Changes in the mechanical properties of the materials also become important when they are intended to withstand loads during implantation. Therefore, the influence of degradation on the mechanical performance of the non-crosslinked and crosslinked soy was also evaluated.

Treatment of soy with glyoxal or exposure to heat decreased the free amine group content of the material, evidencing the role of these groups on the crosslinking reactions (Table 1). The lowest free amine group content was observed for soy crosslinked with $0.6 \%$ glyoxal $\left(0.6 \mathrm{X}-\mathrm{SI}_{\mathrm{tp}}\right)$. Furthermore, the free amine group contents vary from $97.6 \%$ for $\mathrm{SI}_{\mathrm{tp}}$, to $55.9 \%$ and $72.2 \%$ for $0.6 \mathrm{X}-\mathrm{SI}_{\mathrm{tp}}$ and $24 \mathrm{TT}-\mathrm{SI}_{\mathrm{tp}}$, respectively. However, the behaviour of each material (Figs. 1 and 2) should be related not only with its degree of crosslinking but also with the respective nature.

The use of glyoxal leads to the crosslinking between the free amine groups of soy and the aldehyde groups of glyoxal. As previously discussed [22], the resulting crosslinks are mainly of intramolecular nature. Thus, the degradation behaviour of the glyoxal treated materials should be mainly related with their intramolecular crosslinking density. As observed in Fig. 3, the weight loss of these crosslinked samples was always directly proportional to its crosslinking density and always substantially lower than $\mathrm{SI}_{\text {tp }}$ specimens (Figs. 1 and 2).

The heat treatment of the soy materials results in the establishment of: i) crosslinks with the free amine groups (intramolecular crosslinking); ii) disulphide bonding (of intermolecular nature [22]); iii) hydrogen bonding; and iv) hydrophobic interactions. Consequently, the degradation behaviour of the heat treated materials (Figs. 1 and 2) should result from the combined effect of the respective intra- and intermolecular crosslinking density and degree of hydrophobicity. For 
this reason, in both media (Fig. 5), these materials always present degradation rates slower than those predicted only taking into considering the contribution of the intramolecular crosslinks.

It has been shown that enzymatic degradation of polyesters occurs by a surface erosion process which is experimentally characterized by a zero order weight loss in the initial stage of the degradation [38]. A zero order weight loss was always observed in this work for the degradation of either non-crosslinked or crosslinked soy, during the first hours of immersion (Figs. 1a and 2a). This suggests that the degradation of soy materials can be depicted as a surface erosion process. These conclusions can also be supported by the observed decrease in the thickness of the tested bars as a function of immersion time (Figs. $1 \mathrm{~b}$ and $2 \mathrm{~b}$ ), specially during the enzymatic degradation (Fig. 2b). In general, the decrease in the overall samples thickness corresponded to the percentage of material lost due to degradation (Figs. 1 and 2).

The very important changes in mechanical properties during the immersion period (Figs. 6 and 7) revealed a clear two stage process. Furthermore, it is also evident that this behaviour is the result of other contribution than only the degradation (and consequent weight loss) of the soy matrix.

In fact, if crosslinking prevents the penetration of the degrading solution in the protein matrix and only surface erosion occurs, the crosslinked materials would be able to retain the strength for a longer period during degradation. However, it was observed an increase in both strength and stiffness of the materials, accompanied by a sharp decrease in strain at break. As reported previously for other biopolymers containing glycerol [39], the degradation of these polymeric systems always involves the leaching of the plasticiser. So, the evidenced mechanical behaviour can be divided in two distinct phases:

a) First, glycerol is leached during the first three hours of immersion and masked the effects of the matrix degradation on the mechanical properties of the materials. This process is followed by an increase in the material stiffness and a severe loss of ductility (the strain at break drops to values between 1 and $6 \%$ ); b) The behaviour in the second stage, after $3 \mathrm{~h}$ of immersion, should be explained by the following mechanisms: i) as the matrix degradation occurs it enables a moisture uptake by the materials, which can slightly compensate the glycerol loss; ii) so, the strength and stiffness decrease and tend to stabilise, what is followed by a small increment and stabilization of the ductility (Figs. 6c and 7c); iii) these effects are less pronounced in the crosslinked materials because the water uptake of the respective macromolecular structures is more restricted; in fact, glyoxal crosslinked materials $\left(0.6 \mathrm{X}-\mathrm{SI}_{\mathrm{tp}}\right)$ are more stable than the thermal treated ones (24TT-SI ${ }_{\text {tp }}$ ) because the intramolecular crosslinks are important on preventing the referred water uptaking process; and iv) comparison between Figs. 6 and 7 show that, in general terms, the above referred processes are enhanced when the degradation occurs in the presence of enzymatic action.

\section{Conclusions}

Crosslinking of $\mathrm{SI}_{\mathrm{tp}}$ with glyoxal $\left(\mathrm{X}-\mathrm{SI} \mathrm{I}_{\mathrm{tp}}\right)$ or by heat treatment $\left(24 \mathrm{TT}-\mathrm{SI}_{\mathrm{tp}}\right)$ result in materials with different characteristics concerning mechanical properties and invitro stability. The susceptibility of the materials towards (non-) or enzymatic degradation could be controlled by varying the degree of crosslinking or hydrophobicity of the samples. Different degrees of crosslinking could be achieved using glyoxal or heat treatment. Samples crosslinked using the former method seemed to be more resistant toward degradation by a solution of bacterial collagenase. Contrarily, heat treated samples proved to be more resistant to degradation in the absence of collagenase. Upon degradation, the change in mechanical properties of $\mathrm{SI}_{\mathrm{tp}}, 0.6 \mathrm{X}-\mathrm{SI}_{\mathrm{tp}}$ and $24 \mathrm{TT}^{-} \mathrm{SI}_{\mathrm{tp}}$ samples were more sensitive to the leaching of glycerol than to matrices degradation. In general, soy thermoplastics are slightly sensitive to degradation with collagenase.

\section{Acknowledgements}

Cláudia M. Vaz acknowledges: i) Portuguese Foundation for Science and Technology (FCT), Ministry of Science and Technology, Portugal, for the attribution of a PRAXIS XXI PhD Grant; and ii) Dr. Johan Vereijken, ATO BV, The Netherlands, for its valuable comments on this manuscript.

\section{References}

[1] Gogolewsky S. Selected topics in biomedical polyurethanes. A review. Colloid Polym Sci 1989;267:757-85.

[2] Pego AP, Poot AA, Grijpma DW, Feijen J. Copolymers of trimethylene carbonate and $\epsilon$-caprolactone for porous nerve guides: synthesis and properties. J Biomater Sci: Polym Ed 2001;12(1): $35-53$.

[3] Tams J, Joziasse CAP, Bos RRM, Rozema FR, Grijpma DW, Pennings AJ. High-impact poly(d/l lactide) for fracture fixation: in vitro degradation and animal pilot study. Biomaterials 1995; 16:1409-15. 
[4] Chen G, Ushida T, Tateishi T. Hybrid materials for tissue engineering: a preparative method for PLA or PLA-collagen hybrid sponges. Adv Mater 2000;12:455-7.

[5] Danniels AU, Adriano KP, Smuts WP, Chang MKO, Keller J. Evaluation of absorbable poly(ortho esters) for use in surgical implants. J Appl Biomater 1994;5:51-64.

[6] Adriano KP, Pohjonen T, Tomalla P. Processing and characterization of absorbable polylactide polymers for use in surgical implants. J Appl Biomater 1994;5:133-40.

[7] Koller I, Owen AJ. Starch filled PHB and PHB/HV copolymer. J Polym Int 1996;39:175-81.

[8] Hao J, Deng X. Semi-interpenetrating networks of bacterial poly(3-hydroxybutyrate) with net-poly(ethylene glycol). Polymer 2002;42:4091-7.

[9] Rovira A, Amedee J, Bareille R, Rabaud M. Colonization of a calcium phosphate/elastin-solubilized peptide collagen composite material by human osteoblasts. Biomaterials 1996;17:1535-40.

[10] Choi YS, Hong SR, Lee YM, Song KW, Park MH, Nam YS. Study of gelatin-containing artificial skin: I. Preparation and characteristics of novel gelatin-alginate sponge. Biomaterials 1999;20:409-17.

[11] Maeda M, Kadota K, Kajihara M, Sano A, Fujioka K. Sustained release of human growth hormone (hGH) from collagen film and evaluation of effect on wound healing in $\mathrm{db} / \mathrm{db}$ mice. J Controlled Rel 2001;77:261-72.

[12] Sivakumar M, Panduranga Rao K. Preparation, characterization and in vitro release of gentamicin from coralline hydroxyapatitegelatin composite microspheres. Biomaterials 2002;23:3175-81.

[13] Zhang Y, Chu C-C. Biodegradable dextran-polylactide hydrogel networks: their swelling, morphology and the controlled release of indomethacin. J Biomed Mater Res 2001;59:318-28.

[14] Barralet JE, Aldred S, Wright AJ, Coombes AGA. In vitro behaviour of albumin-loaded carbonate hydroxyapatite gel. J Biomed Mater Res 2002;60:360-7.

[15] Park S-B, You J-O, Park H-Y, Haam SJ, Kim W-S. A novel pHsensitive membrane from chitosan-TEOS IPN; preparation and its drug permeation characteristics. Biomaterials 2001;22:323-30.

[16] Kilshaw PJ, Sissons JW. Allergenicity of soy proteins. Res Vet Sci 1979;27:361-72.

[17] Vaz CM, Fossen M, Tuil RF, de Graaf LA, Reis RL, Cunha AM. Casein and soybean protein-based thermoplastics and composites as alternative biodegradable polymers for biomedical applications. J Biomed Mater Res 2003;65A:60-70.

[18] Silva GA, Vaz CM, Coutinho OP, Cunha AM, Reis RL. In vitro degradation and cytocompatibility of novel soy and sodiumcaseinate-based membrane biomaterials. Biomaterials [submitted for publication].

[19] Otaigbe JU, Adams DO. Bioabsorbable soy protein plastic composites: Effect of polyphosphate fillers on water absorption and mechanical properties. J Environ Polym Degrad 1997;5(4):199-208.

[20] Paetau I, Chen C-Z, Jane J. Biodegradable plastic made from soybean products. II. Effects of crosslinking and cellulose incorporation on the mechanical properties and water absorption. $\mathrm{J}$ Environ Polym Degrad 1994;2(3):211-7.

[21] Paetau I, Chen C-Z, Jane J. Biodegradable plastics made from soybean products. 1. Effects of preparation and processing on mechanical properties and water absorption. Ind Eng Chem Res 1994;33:1821-7.
[22] Vaz CM, van Doeveren PFNM, Yilmaz G, de Graaf LA, Reis RL, Cunha AM. Processing and characterization of biodegradable soy thermoplastics: effect of crosslinking with glyoxal and thermal treatment. J Appl Polym Sci [submitted for publication].

[23] Prudencio-Ferreira SH, Areas JA. Protein-protein interactions in the extrusion of soya at various temperatures and moisture contents. J Food Sci 1993;58:378-81.

[24] Olde Damink LHH, Dijkstra PJ, van Luyn MJA, van Wachem PB, Nieuwenhuis P, Feijen J. In vitro degradation of dermal sheep collagen cross-linked using a water soluble carbodiimide. Biomaterials 1996;17(7):679-84.

[25] Olde Damink LHH, Dijkstra PJ, van Luyn MJA, van Wachem $\mathrm{PB}$, Nieuwenhuis P, Feijen J. Changes in the mechanical properties of dermal sheep collagen during in vitro degradation. J Biomed Mater Res 1995;29:139-47.

[26] Wong SS, editor. Chemistry of protein conjugation and crosslinking. Boca Raton: CRC Press; 1991.

[27] Golomb G, Schoen FJ, Smith MS, Linden J, Dixon M, Levy RJ. The role of glutaraldehyde-induced crosslinks in calcification of bovine pericardium used in cardiac valve bioprostheses. Am J Pathol 1987;127:122-30.

[28] van Luyn MJA, van Wachem PB, Olde Damink LHH, Dijkstra PJ, Feijen J, Nieuwenhuis P. Secondary cytotoxicity of crosslinked dermal sheep collagens during repeated exposure to human fibroblasts. Biomaterials 1992;13:1017-24.

[29] van Luyn MJA, van Wachem PB, Olde Damink LHH, Dijkstra PJ, Feijen J, Nieuwenhuis P. Relations between in vitro cytotoxicity and crosslinked dermal sheep collagens. J Biomed Mater Res 1992;26:1091-110.

[30] Weadock K, Olson RM, Silver FH. Evaluation of collagen crosslinking techniques. Biomater Med Dev Artif Org 1983;11: 293-318.

[31] Bertrand-Harb C, Nicolas M-G, Dalgalarrondo M, Chobert JM. Determination of alkylation degree by three colorimetric methods and amino acid analysis. A comparative study. Sci Alim 1993;13:577-84.

[32] Tropini V, Lens J-P, Mulder WJ, Silvestre F. Cross-linking of wheat gluten using a water-soluble carbodiimide. Cereal Chem 2000;77(3):333-8

[33] ISO 62. Plastics - determination of water absorption. International Organization for Standardization; 1980.

[34] Crank J, editor. Mathematics of diffusion. Oxford: Clarendon; 1975.

[35] Lee JM, Edwards HL, Pereira CA, Samii SI. Crosslinking of tissue-derived biomaterials in 1-ethyl-3-(dimethylaminopropyl)-carbodiimide. J Mater Sci: Mater Med 1995;6(7):429-34.

[36] Simmons DM, Kearney JN. Evaluation of cross-linking techniques for the stabilisation of tissue matrices. Biotech Appl Biochem 1993;17:23-9.

[37] Cheung DT, Perelman N, Ko EC, Mimni ME. Mechanism of cross-linking of proteins by glutaraldehyde. III. Reaction with collagen in tissues. Conn Tissue Res 1985;13:109-15.

[38] Pitt CG, Hendren RW, Schindler A, Woodward SC. The enzymatic surface erosion of aliphatic polyesters. J Controlled Rel 1984;1:314.

[39] Vaz CM, Reis RL, Cunha AM. Degradation model of starchEVOH/HA composites. Mater Res Innovations 2001;4(5/6):37580 